\title{
SPATIAL DISTRIBUTION OF SPONTANEOUS PRODUCTION OF Attalea maripa (Aubl) Mart. IN THE LOW TOCANTINS ${ }^{1}$
}

\author{
RAIMUNDO DIONÍZIO PINTO BRITO², PAULO ROBERTO DA SILVA FARIAS ${ }^{3}$, \\ NARA ELISA LOBATO RODRIGUES ${ }^{4}$, FABIO JÚNIOR DE OLIVEIRA ${ }^{5}$, \\ RENATO ALVES TEXEIRA ${ }^{6}$
}

\begin{abstract}
The production of biofuels from native Amazonian palm trees, belonging to the family of Arecaceae, like Attalea maripa (Aubl) Mart. (Maripa palm), are objects of studies of alternative energy sources for the biofuels production. Thus, the aim of this research was to evaluate the spatial dynamics of agronomic variables of Maripa palm crop production associated with the characteristics of the sampling sites in a spontaneous growth area in the Low Tocantins region. 100 palms of $A$. maripa were selected, of spontaneous growth and in production phase, on a 10 ha area in the municipality of Cametá / PA, in which the morpho-agronomical variables were collected (MIN, FIN, ABN, LN, DBH, AWAB and AFW), from January 2014 to June 2014. The semivariograms were produced for each variable, which presented a spatial dependence range of 75 meters to MIN, FIN, AWAB and AFW, 80 meters to LN and DBH and 98 meters to ABN. The area of reach found was $17,671.5 \mathrm{~m}^{2}$ for MIN, FIN, AWAB and AFW variables, $20,106.2 \mathrm{~m}^{2}$ for $\mathrm{LN}$ and $\mathrm{DBH}$ and $30,171.9 \mathrm{~m}^{2}$ for $\mathrm{ABN}$. The data of the variables were adjusted to the spherical model presenting determination coefficient $\left(\mathrm{R}^{2}\right)$ that ranged from 0.57 to 0.99 . The spatial dependence index (SDI) for MIN and FIN variables was 0.49 and 0.31 , respectively, indicating moderate spatial dependence. For ABN, LN, DBH and AWAB variables ranged from 0.17 to 0.22 , resulting in poor spatial dependence. The AFW variable presented SDI of 0.77. For the visual analysis of the spatial distribution of the studied variables, kriging maps were created.
\end{abstract}

Index terms: Spatial dependence, Maripa palm, Kriging, Semivariogram, Variables morphoagronomics.

\section{DISTRIBUIÇÃO ESPACIAL DA PRODUÇÃO ESPONTÂNEA DE Attalea maripa (Aubl) Mart. DO BAIXO TOCANTINS}

\begin{abstract}
RESUMO - A produção de biocombustível a partir de palmeiras nativas da Amazônia, pertencentes à família das Arecaceae, como a Attalea maripa (Aubl) Mart. (inajá), são objetos de estudos de fontes energéticas alternativas para a produção de biocombustíveis. Dessa forma, o objetivo desta pesquisa foi avaliar a dinâmica espacial das variáveis morfoagronômicas de produção da cultura do inajazeiro associado às características dos locais de amostragem, em uma área de crescimento espontâneo, na região do Baixo Tocantins. Foram selecionadas 100 palmeiras de A. maripa, de crescimento espontâneo e em fase de produção, em uma área de 10 ha, no município de Cametá-PA, nas quais foram realizados os levantamentos das variáveis morfoagronômicas (NIM, NIF, NCA, NF, DAP, PMCA e PMF), no período de janeiro de 2014 a junho de 2014. Foram elaborados os semivariogramas para cada variável estudada, que apresentaram um alcance de dependência espacial de 75 metros para NIM, NIF, PMCA e PMF; 80 metros para NF e DAP, e 98 metros para NCA. Já a área de alcance encontrada foi de $17.671,5 \mathrm{~m}^{2}$ para as variáveis NIM, NIF, PMCA e PMF; $20.106,2 \mathrm{~m}^{2}$ para NF e DAP, e $30.171,9 \mathrm{~m}^{2}$ para NCA. Os dados das variáveis se ajustaramse ao modelo esférico, apresentando coeficiente de determinação $\left(\mathrm{R}^{2}\right)$ que variou de 0,57 a 0,99 . $\mathrm{O}$ índice de dependência espacial (IDE) para as variáveis NIM e NIF foi de 0,49 e 0,31 , respectivamente, que indica dependência espacial moderada. Para as variáveis NCA, NF, DAP e PMCA, variaram de 0,17 a 0,22, resultando em dependência espacial fraca. Já a variável PMF apresentou IDE com valor 0,77. Para análise visual da distribuição espacial das variáveis estudas, foram elaborados mapas de krigagem.
\end{abstract}

Termos para indexação: Dependência espacial. Inajá. Krigagem. Semivariograma. Variáveis morfoagronômicas.

\footnotetext{
${ }^{1}$ (Paper 255-15). November 03, 2015. Accepted August 15, 2016.

${ }^{2}$ Technologist in Environmental Control, Master's degree in Agronomy at the Federal Rural University of Amazônia. Email: dionisiobrito@bol.com.br

${ }_{3}^{3}$ Agronomist Engineer, Prof. Dr. at the Federal Rural University of Amazonia, Belém-PA. Email: paulo.farias@ufra.edu.br

${ }^{4}$ Agronomist Engineer Post-doctoral student in the Amazon Federal Rural University. Email: naraelr@hotmail.com

${ }^{5}$ Agronomist Engineer, Doctoral student in the Amazon Federal Rural University. Emails: fjoliveira13@gmail.com; alves.agro@ gmail.com
} 


\section{INTRODUCTION}

Negative environmental impacts in Amazonia, caused mainly by disordered deforestation, inadequate agricultural practices, livestock and illegal occupation of public land, have led to the disappearance of large areas of primary forests and strong soil degradation, resulting in the emergence of large almost homogeneous populations of palm trees, mainly from Attalea maripa (Aubl) Mart. (MIRANDA; RABELO, 2008).

Many species of the Arecaceae family have fruits and seeds with high oil content, with economic potential and a perspective of important appreciation for the region (PALLET, 2002). According to Miranda and Rabelo (2008), this oleaginous species, mainly destined to the feeding of traditional populations, can also form the basis of a self-sustaining technological development model.

Thus, among the palm trees known as "invasive", deserves attention the Maripa palm, from the Arecaceae family, it is distributed in the tropical rainforest of the north of South America, mainly in Brazil, occurring in the states of Acre, Maranhão, Amapá, Amazonas, Pará, Rondônia and Roraima (MORTON et al., 2005). In the adult phase, the Maripa palm is an erect, simple and cylindrical palm tree with no tillers, solitary, reaching in the adult phase $13 \mathrm{~m}$ of height, almost $100 \mathrm{~cm}$ in diameter at breast height (DBH), presents composite leaf, inflorescence, interfoliar bunch protected by persistent spatula that are modified leaves, fruit of the drupe type, containing from one to three seeds (MATOS, 2010). From the fruit is extracted a clear and transparent oil, with excellent physicochemical properties for cooking, as well as raw material for biodiesel production (MOTA; FRANÇA, 2008).

The state of Pará has many areas of native populations of Maripa palm with great representativeness located mainly in the northeast region of Pará (Municipality of Cametá/PA). However, in spite of the oleaginous potential of the fruits (Maripa palm), their natural populations are being gradually eliminated during the cleaning of pastures and by the practice of slash and burning of sponteneous secondary vegetation, used in the preparation of areas for agricultural crops planting. Therefore, in order to provide the economic use of the Maripa palm and its incorporation in the list of commercial non-timber products, it is necessary to expand the research on the characteristics of bunches and fruits, as well as the production and productivity of this promising palm tree. Thus, the aim of this research was to evaluate the spatial dynamics of morpho-agronomical variables of the Maripa palm crop production associated to the characteristics of the sampling sites in an area of spontaneous growth in the Low Tocantins region.

\section{MATERIALS AND METHODS}

The studied area was located in the municipality of Cametá/PA, belonging to the Mesoregion of the Northeast of the state of Para and the Low Tocantins Region, with the geographic coordinates $02^{\circ} 44^{\prime} 54^{\prime \prime}$ south latitude and $49^{\circ} 03^{\prime}$ ' $42^{\prime \prime}$ west longitude of the Greenwich Meridian. The climate is classified as AMI, according to Köppen (1948), with an annual average temperature of approximately $25^{\circ} \mathrm{C}$ and rainfall around $2,250 \mathrm{~mm}$ annually, with a higher concentration from January to June, representing around $80 \%$ of the total. The average air relative humidity is around $85 \%$.

The study of the Maripa palm populations was carried out at the Continental Farm, which has an approximate area of 30 ha of spontaneous Maripa palm trees, with an estimated of 40 palms/ha, being selected an area of 10 ha and within that area were evaluated 100 palm trees of Maripa palms, free of pollination, with approximately 20 years old.

The palms were selected at random (Figure 1), obeying a minimum distance between plants of approximately $6 \mathrm{~m}$ within the selected area. Then, they were spatially located through the collection of their geographic coordinates (UTM).

The Morpho-agronomical parameters were evaluated in Maripa palms in areas with different uses, pasture, sponteneous secondary vegetation, flood and forest. The morpho-agronomical parameters studied were diameter at breast height (DBH), male inflorescence number (MIN) and female (FIN), leaves number (LN), androgynous bunch number $(\mathrm{ABN})$, average weight of the androgynous bunch (AWAB) and average fruit weight (AFW).

To evaluate the morpho-agronomical variables spatially, a map of the sampling sites of the plants was elaborated (Figure 3A), and the types of environment observed in these areas were determined. The observed environments refer to flooded areas or areas subject to floods, pasture, sponteneous secondary vegetation and forest.

The DBH of the stem was measured at 1.30 $\mathrm{m}$ from the soil, using a tape measure, and then the circumference was measured. For the determination of the MIN and FIN, the inflorescences were collected with the aid of a sickle of the Malaysian type, sexed and checked.

The leaf number (LN) evaluation was carried 
out with the aid of a reinforced fiberglass ladder of two throws, measuring six meters, with all the leaves of each plant counted.

For the determination of the ABN and AWAB, the androgynous bunches were collected manually with the aid of a adjustable rod for six meters with a Malayan type sickle at the top and then transported by tractors to the premises of the factory of the green oils of Amazon plant, in which all bunches were counted, individually weighed on an English scale, then the length and circumference of the apex, middle and base of the bunch were measured with the aid of a millimeter scale.

After collecting the bunches, all of them were placed together in an industrial harvester designed for Maripa palm and the separation of the fruits from the ráqui and ráquilas (components of the empty bunch), the loose fruits were weighed in an English scale to estimate the average weight of the fruits.

In addition, the chemical characteristics of the soil were evaluated, and four simple soil samples were collected at $0-0.2 \mathrm{~m}$ depth, which subsequently formed a composite sample for each studied area. The phosphorus $(\mathrm{P})$ and the potassium $(\mathrm{K})$ were extracted by Mehlich-1 and determined by spectrophotometry and flame photometry respectively. The calcium $(\mathrm{Ca})$, magnesium $(\mathrm{Mg})$ and aluminum $(\mathrm{Al})$ were extracted with $\mathrm{KCl} 1 \mathrm{~mol} \mathrm{~L}^{-1}$ and determined by titration. The $\mathrm{pH}$, in potentiometer in the soil: water relation of $1: 2.5$. The total organic carbon (TOC), by the volumetric method of oxidation with $\mathrm{K}_{2} \mathrm{Cr}_{2} \mathrm{O}_{7}$ and titration with ammonium ferrous sulfate, the organic matter was estimated by multiplying the TOC by 1.72 (EMBRAPA, 2011).

For the spatial distribution analysis of the production, the geostatistics was used, from the semivariogram modeling and the creation of kriging maps. For this procedure, the position information of each sample and the values observed at each point were used. Each plant had its known location, with its coordinates (UTM) in units of measures that enabled the calculation of the distance between plants (VIEIRA et al., 1983).

Then, semivariograms were elaborated, which defined the parameters referring to the semivariogram: the threshold $\left(C\right.$ or $\left.C_{0}+C_{1}\right)$, the spatial variance $\left(C_{1}\right)$, the nugget effect $\left(C_{0}\right)$ and the range $(a)$, through the estimation of the semivariogram, according to the equation below.

$$
\gamma^{*}(h)=\frac{1}{2 N(h)} \sum_{i=1}^{N(h)}\left[Z\left(x_{t}\right)-Z\left(x_{t}+h\right)\right]^{2}
$$

Where $\mathrm{N}(\mathrm{h})$ is the number of pairs of measured values $\mathrm{Z}\left(x_{i}\right) \mathrm{Z}\left(x_{i}+\mathrm{h}\right)$, separated by a vector $\mathrm{h} . \gamma^{*}(\mathrm{~h})$ is the semivariance given in function of the distance, so it depends on the direction of $h$.

The data were tested to the experimental models with threshold and adjusted according to their behaviors. The models were determined according to the determination coefficient $\left(\mathrm{R}^{2}\right)$, selecting those that presented higher values. The experimental models used were spherical, exponential, Gaussian and random (pure nugget effect).

From the adjustments, the parameters of the experimental semivariograms were calculated using the Spatial Dependency Indexes (SDI), $k$ parameter, which is the relation between $C_{1} /\left(C_{0}+C_{1}\right)$ to determine the spatial dependence of each evaluation, and classified according to the intervals proposed by Zimback (2001) where the SDI values $<0.25$ is considered weak dependence, values of $0.25 \leq \mathrm{SDI} \geq$ 0.75 are considered moderate and, values $>0.75$ are considered with strong spatial dependence.

For the creation of the kriging maps and evaluation of the study, it was necessary to interpolate the points sampled to obtain an estimate, given by the following equation:

$$
Z^{*}\left(x_{0}\right)=\sum_{i=1}^{N} \lambda_{i} Z\left(x_{i}\right)
$$

Where:

$z^{*}=$ estimate;

$x_{0}=$ linear combination of values of neighboring measures;

$N=$ number of measured values involved in the estimate $z\left(x_{i}\right) ; \lambda_{i}=$ weight associated with each measured value.

For the elaboration, adjustments of semivariograms and the creation of kriging maps the Surfer 8.0 software was used.

\section{RESULTS AND DISCUSSION}

The different soil use systems showed low levels of $\mathrm{Ca}, \mathrm{Mg}, \mathrm{P}$ and $\mathrm{K}$, (Table 1). The low concentration of exchangeable bases and high acidity, $\mathrm{pH}$ ranging from 4.3 to 5.3 are related to the leaching of significant quantities of the soil exchangeable bases caused by the high precipitation of the region. In addition, the soils of the region are poor in primary minerals responsible for the replacement of exchangeable bases in the soil (CRAVO et al., 2007).

The spatial dependence of the variables was 
studied through semivariograms, presenting better adjust of the data to the spherical model, which provided the highest determination coefficient for all evaluations (Figure 2). The parameters of the semivariograms adjusted for the variables under study can be observed in Table 2 .

Semivariograms were then elaborated for each studied variable (Figure 2A to $G$ ), which presented a spatial dependence range of 75 meters for MIN, FIN, AWAB and AFW, 80 meters for LN and DBH and 98 meters for ABN (Table 2).

The aggregation radius of the variables in the field is provided by the spatial dependence range, which allows making an analysis of the production within the studied area. From the radius of variables aggregation, it was estimated the area of reach for each variable which results in the influence of the same for the plants. The range area was $17,671.5$ $\mathrm{m}^{2}$ for MIN, FIN, AWAB and AFW, 20,106.2 $\mathrm{m}^{2}$ for $\mathrm{LN}$ and DBH and 30,171.9 $\mathrm{m}^{2}$ for ABN (Table 2).

From the range area, it was possible to identify, through the maps, which morpho-agronomical variables are related to each other and those with the soil chemical attributes content in each type in each type of soil use studied, being able to indicate in what type of soil use there is higher plant yield.

Regarding the spatial dependence index (SDI), for the MIN and FIN variables, moderate spatial dependence was observed, with indexes of 0.49 and 0.31 , respectively. For the ABN, LN, DBH and $\mathrm{AWAB}$ variables ranged from 0.17 to 0.22 , resulting in weak spatial dependence. The AFW variable presented SDI with a value of 0.77 , with strong spatial dependence (Table 2).

The semivariograms adjusted to the models are shown in Figure 2, which presented adjustments to the spherical model, presenting determination coefficient $\left(\mathrm{R}^{2}\right)$ ranging from 0.57 to 0.99 , which justifies the aggregate distribution of the variables in the studied area.

Through the adjusted models to the semivariograms, it was possible to estimate the sampled values by the ordinary kriging method to construct the maps of the studied areas and the spatial distribution of morpho-agronomical characteristics (Figure 3), which allows the identification of homogeneous subareas, thus enabling an adequate management of the Maripa palm in the different areas.

According to the kriging maps, it was verified from the interpolation, that all variables formed coppices inside the area (Figure 3).

From the visual analysis of the sampling area maps and the kriging maps of the morpho- agronomical variables, we observed that in areas subject to flooding, the MIN was higher, while in the pasture environment these values were reduced by half (Figure 3B), and may be related to the availability of water and/or light of the area.

According to Salm et al. (2015) the A. maripa show low tolerance to floods, obtaining a greater affinity for dry land, fact that may have influenced the greater emission of male inflorescences in this research.

For the FIN, the forest area provided higher values, but in the flooded and sponteneous secondary vegetation areas there were isolated sites that also presented high values. However, in the flooded area, isolated sites with reduced FIN were also observed (Figure 3C). These isolated sites may be related to the genotypic characteristics of certain palms and/ or such sites are close to other forest areas and/or nutrient availability.

For the ABN, in flooded areas, there is a significant decrease in the production of androgynous bunches, and in other places, these values were satisfactory (Figure 3D). However, the occurrence of isolated sites in the sponteneous secondary vegetation and pasture areas with low production of androgynous bunches was observed, which may be correlated with plant nutrition in the area. This fact is proven when the values obtained from AWAB and AFW were also observed, which were also low for flooded areas and at these isolated sites in the areas of sponteneous secondary vegetation and pasture, ranging from 17 to $42 \mathrm{~kg}$ for $\mathrm{AWAB}$ and 12 to $52 \mathrm{~kg}$ for AFW in all the areas.

In addition, the lowest average yields occurred in areas of floods $(51.52 \mathrm{~kg})$ and pasture $(56.36 \mathrm{~kg})$, when compared to areas of forest $(71.60$ $\mathrm{kg})$ and sponteneous secondary vegetation $(72.81$ $\mathrm{kg}$ ). According to Duarte (2008), the satisfactory index for the production of androgynous bunches varies from 3 to 5 bunches per palm tree per year with an average weight of $35 \mathrm{~kg}$, corroborating with the results obtained in this research.

For the LN, the most significant values are observed in pasture and forest areas, and less significant in flooded and sponteneous secondary vegetation areas (Figure 3E). The lowest values for DBH also occurred in flooded and sponteneous secondary vegetation areas, but it was not generalized for all areas but for isolated sites of plants (Figure $3 \mathrm{~F})$. Beside that, the DBH AWAB and AFW variables presented higher values in the forest area (Figure 3F, G and $\mathrm{H}$ ) and pasture, only for the $\mathrm{DBH}$ variable (Figure 3F). According to Clark et al. (1995), the palm production is strongly influenced 
by environmental conditions and may lead to different responses due to environmental changes, thus, it can be stated that the low emission of leaves, $\mathrm{DBH}, \mathrm{AWAB}$ and AFW in the areas of sponteneous secondary vegetation and flooded was influenced by soil and climate conditions.

Among the main management and maintenance activities of the plantation of some palm trees are: the crowning of the plants, skimming of the interlines, elimination of invasive plants, plant health, pruning, harvest and collection of the bunches and, the supervised pollination (BERTHAUD et al., 2000).Thus, this lack of management and maintenance of the $A$. maripa spontaneous palms in the areas of sponteneous secondary vegetation and flooded were possibly determinants facts that influenced the less expressive values in these areas. Thus, the adoption of cultural practices in a correct way and at the appropriate time would be of fundamental importance for the good development and production of these palm trees.

From the soils chemical characteristics at the four sampling sites and associating them with the low yields of the spontaneous populations found at some sampling sites in this region (Table 1 and Figure 3), we can assume that the mineral nutrition may also have exerted an influence on the production components of $A$. maripa. It is observed that other palm trees such as the palm oil crop have a significant demand for nutrients (SOH, 1997). Beside that, other factors such as nutritional requirement vary widely, depending on the yield required, the type of genetic material used, spacing, plant age, soil type and environmental factors. Environmental factors can significantly influence soil properties (CHAPLOT et al., 2001; OLLINGER et al., 2002) and reflect this on palm production. Kusnu et al. (1996) found an increase in the bunch weight when evaluating the growing effect of potassium doses on the palm oil crop.

The results presented in the spontaneous Maripa palm trees show that this material is in good reproductive state in pasture and forest areas (Figure 3). This population, for characteristics like AWAB, $\mathrm{ABN}$, and LN, meets the selection standards used (DUARTE, 2008).

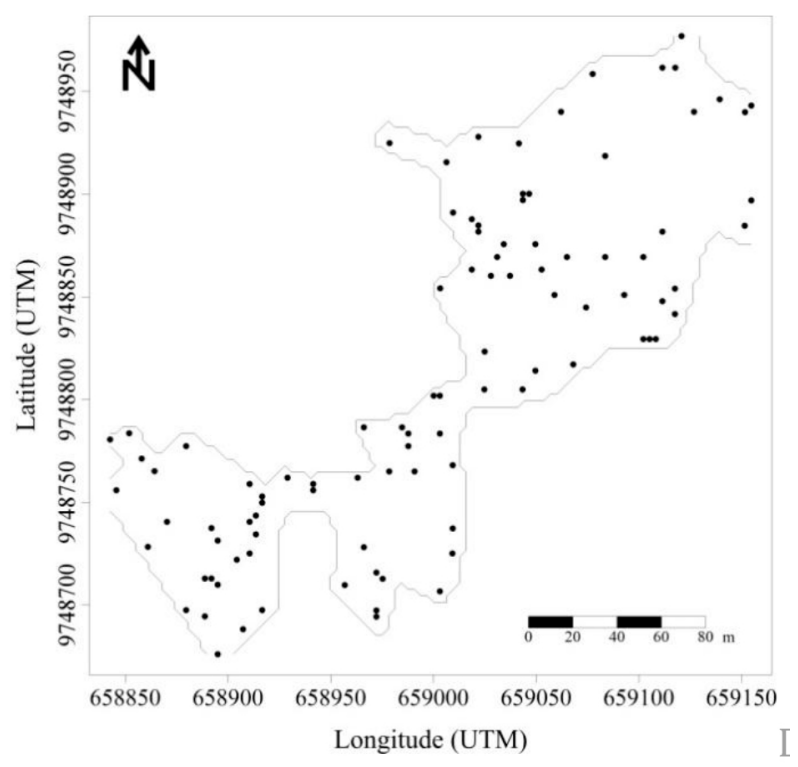

FIGURE 1- Location of the georeferenced palm trees. The points represent the spatial location of each plant within the studied area. 

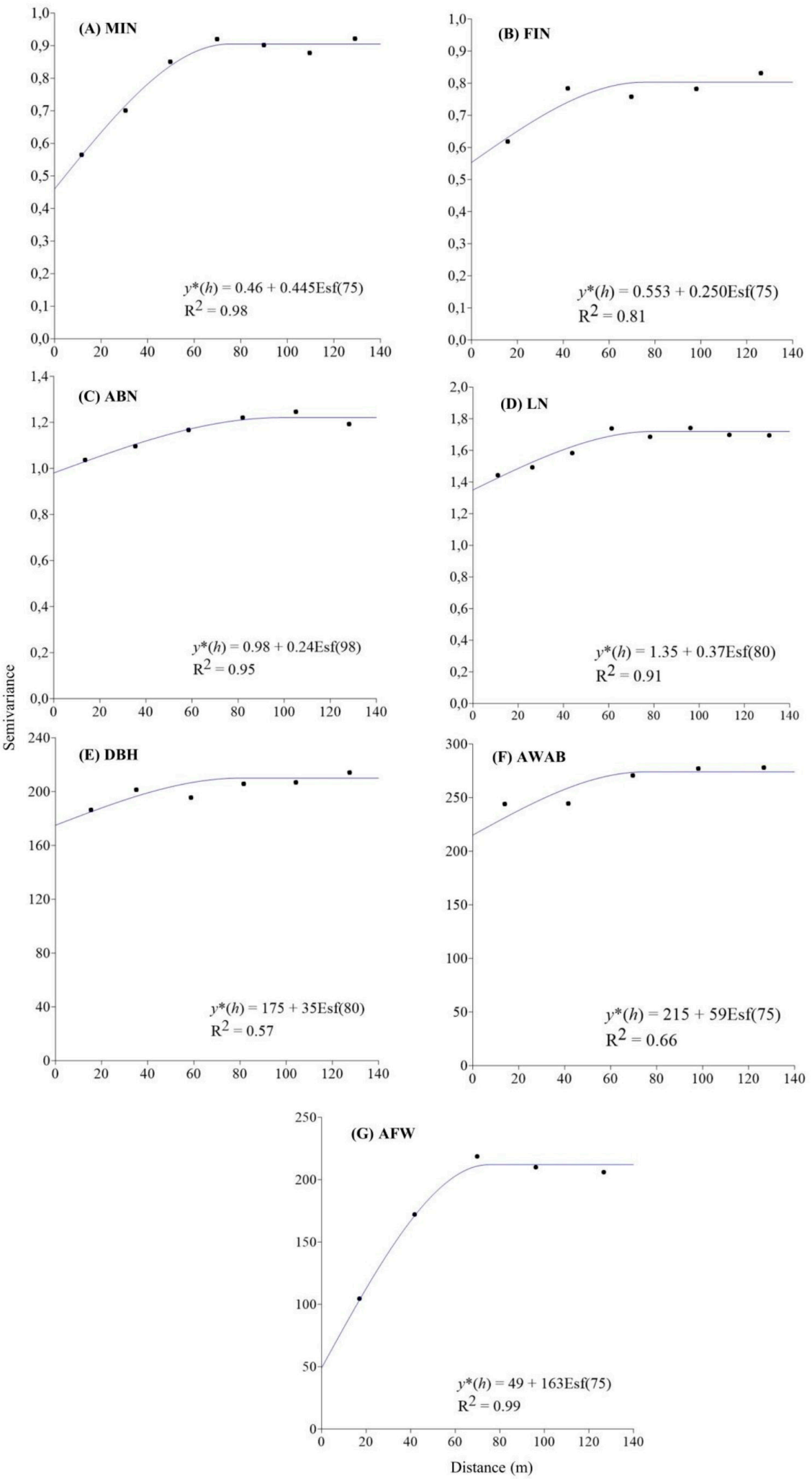

FIGURE 2- Semivariograms of an area of 10 ha of Maripa palm plantation (Attalea maripa (Aubl) Mart.) in the municipality of Cametá, PA, from January to March, 2014. 

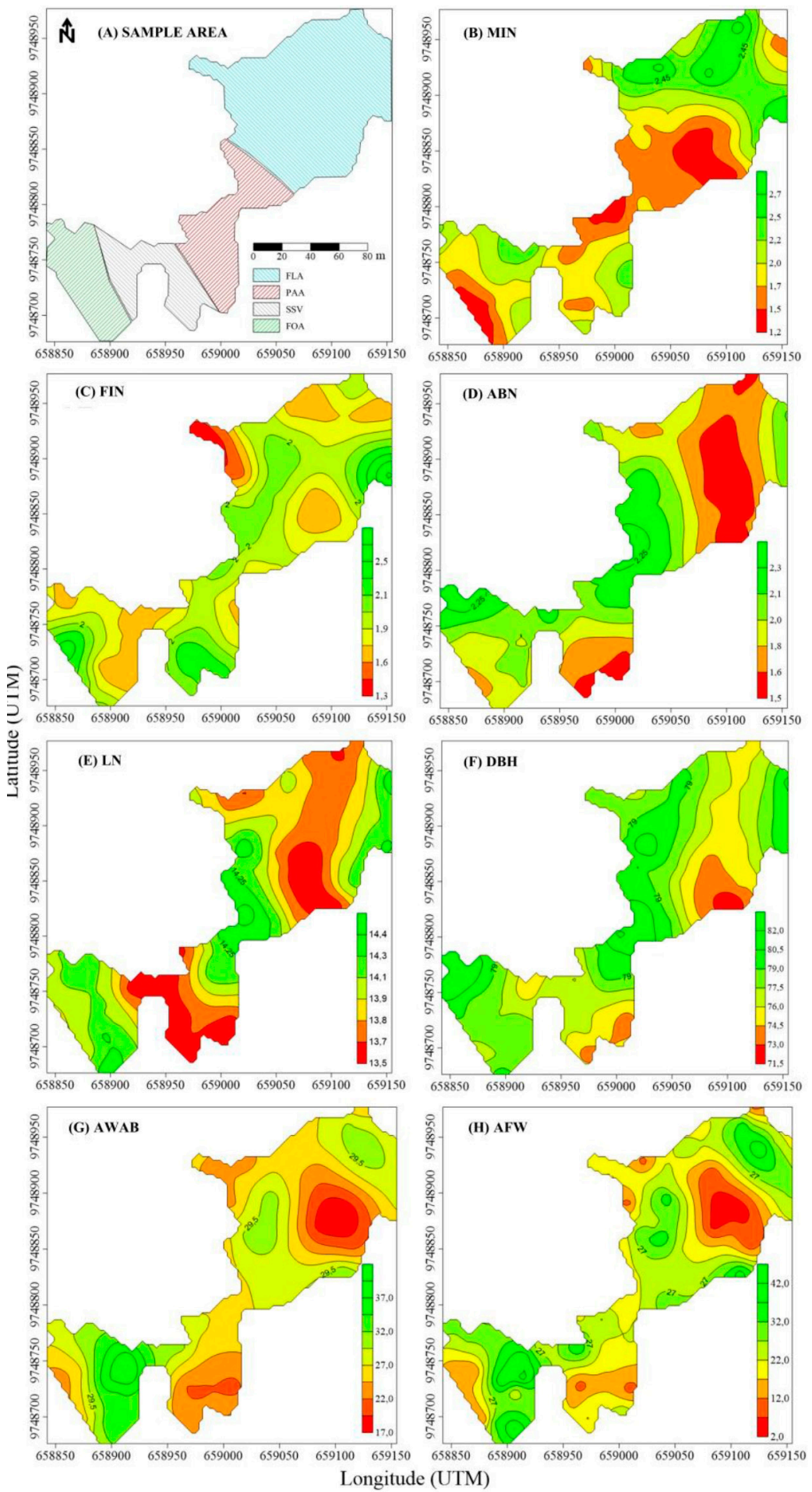

FIGURE 3-(A) Map of the sampling sites (and maps of the spatial distribution of (B) male inflorescence number (MIN), (C) female inflorescence (FIN), (D) androgynous bunches (ABN), (E) leaves number $(\mathrm{LN}),(\mathrm{F})$ diameter at breast height (DBH), $(\mathrm{G})$ average weight of androgynous bunches (AWAB) and $(\mathrm{H})$ average fruit weight (AFW) of an area of 10 ha of maripa palm tree plantation (Attalea maripa (Aubl) Mart.) in the municipality of Cametá, PA, from January 2014 to March 2014. 
TABLE 1- Result of the analysis of soil chemical attributes in the different environments within the study area.

\begin{tabular}{cccccccccccc}
\hline \multirow{2}{*}{ Collection site } & $\mathrm{OM}^{1}$ & $\mathrm{pH}$ & $\mathrm{Ca}$ & $\mathrm{Mg}$ & $\mathrm{P}$ & $\mathrm{K}$ & $\mathrm{H}+\mathrm{Al}$ & $\mathrm{CEC}^{2}$ & $\mathrm{BS}^{3}$ & $\mathrm{~V}(\%)^{4}$ \\
\cline { 7 - 12 } & $\mathrm{g} \mathrm{kg}^{-1}$ & $\mathrm{H}_{2} \mathrm{O}$ & & & \multicolumn{5}{c}{$\mathrm{cmol}_{\mathrm{c}} \mathrm{dm}^{3}$} \\
\hline Flooded Area & 3.9 & 4.3 & 2.2 & 1.2 & 157.6 & 90.7 & 1.1 & 13.2 & 7.1 & 53.7 \\
Pasture Area & 4.5 & 5.0 & 2.5 & 0.9 & 212.7 & 4.1 & 3.5 & 15.08 & 7.8 & 50.2 \\
Spontaneous secondary & 6.4 & 5.3 & 2.0 & 1.7 & 135.2 & 1.7 & 2.6 & 13.0 & 5.4 & 41.5 \\
vegetation Area & & & & & & & & & & \\
Forest Area & 3.7 & 5.1 & 2.9 & 0.6 & 5.7 & 1.2 & 1.0 & 13.1 & 6.1 & 46.5 \\
\hline
\end{tabular}

${ }^{1}$ Organic Matter, ${ }^{2}$ Cation Exchange Capacity, ${ }^{3}$ Base Sum, ${ }^{4}$ Base Saturation

TABLE 2 - Semivariogram parameters adjusted to the models, determination coefficient $\left(\mathrm{R}^{2}\right)$ and k parameter for the geostatistical analysis in an area of 10 ha of Maripa palm plantation (Attalea maripa (Aubl) Mart.) in the municipality of Cametá, PA, in the period from January 2014 to March 2014.

\begin{tabular}{|c|c|c|c|c|c|c|c|}
\hline \multirow{2}{*}{ VARIABLE } & \multicolumn{3}{|c|}{ Semivariogram parameters } & \multirow{2}{*}{ Range area $\left(\mathrm{m}^{2}\right)^{\mathrm{a}}$} & \multirow{2}{*}{$\mathrm{R}^{2}$} & \multirow{2}{*}{$k^{\mathrm{b}}$} & \multirow{2}{*}{$\begin{array}{c}\text { Spatial } \\
\text { Dependence }\end{array}$} \\
\hline & $C_{o}$ & $C_{1}$ & $a(m)$ & & & & \\
\hline MIN & 0.460 & 0.445 & 75 & 17671.5 & 0.98 & 0.49 & MODERATED \\
\hline FIN & 0.553 & 0.250 & 75 & 17671.5 & 0.81 & 0.31 & MODERATED \\
\hline $\mathbf{A B N}$ & 0.980 & 0.240 & 98 & 30171.9 & 0.95 & 0.20 & WEAK \\
\hline $\mathbf{L N}$ & 1.350 & 0.370 & 80 & 20106.2 & 0.91 & 0.22 & WEAK \\
\hline DBH & 175.000 & 35.000 & 80 & 20106.2 & 0.57 & 0.17 & WEAK \\
\hline AWAB & 215.000 & 59.000 & 75 & 17671.5 & 0.66 & 0.22 & WEAK \\
\hline AFW & 49.000 & 163.000 & 75 & 17671.5 & 0.99 & 0.77 & STRONG \\
\hline
\end{tabular}

${ }^{a}$ Calculated by $\pi \cdot \mathrm{r}^{2}$, where $\pi=3.14$ and $\mathrm{r}=\mathrm{a}$

${ }^{\mathrm{b}}$ Relation between $C_{l} /\left(C_{o}+C_{l}\right)$.

\section{CONCLUSION}

The spherical model best represents the spatial distribution of the Maripa palm tree production variables, which indicates an aggregate distribution pattern of the morpho-agronomical variables in the field.

Spontaneous Maripa palm tree populations, although they are older in the field, have a good reproductive status, in relation to the Average Weight of Androgynous Bunches (AWAB), Average Fruit Weight (AFW) and Leaves Number (LN).

The pasture area provides higher values for diameter under the bifurcation point, leaves number and number of androgynous bunches, which indicates that the area is more suitable for a better production of Maripa palm tree.

The association of low yields of some morpho-agronomical characteristics with the sampling sites indicates the need to prioritize the selection of genotypes to increase the production of these palms in this region.

\section{REFERENCES}

ANDERSON, L. O.; SHIMABUKURO, Y. E.; LATORRE, M. L.; ESPÍRITO-SANTO, F. DEL B.; LIMA, A.; DUARTE, V.; ARAI, E.; DEFRIES, R. S.; MORTON, D.; HANSEN, M.; JASINSKY, E. Coleta de dados para estudos de cobertura arbórea, mapeamento da cobertura da terra, desmatamento e avaliação de unidades de conservação/territórios indígenas: metodologias de trabalhos de campo. Brasília: Instituto Nacional de Pesquisa Espacial, 2005. 37p.

BERTHAUD, A.; NUNES, C. D. M.; BARCELOS, E.; CUNHA, R. N. V. da. Implantação e exploração da cultura do dendezeiro. In: VIÉGAS, I. de J. M.; MÜLLER, A. A. (Ed.). A cultura do dendezeiro na Amazônia Brasileira. Belém: Embrapa Amazônia Oriental, Manaus: Embrapa Amazônia Ocidental, 2000. p.193-227. 
CHAPLOT, V.; BERNOUX, M.; WATLER, C.; CURMI, P.; HERPIN, U. Soil carbon storage prediction in temperate hydromorphic soils using a morphologic index and digital elevation model. Soil Science, Baltimore, v.166, p.48-60, 2001.

CLARK, D.A.; CLARK, D.B.; SANDOVAL, M.R.;CASTRO, C.M.V. Edaphic and human effects on landscape-scale distributions of tropical rain forest palms. Ecology, Brooklyn, v.76, p.2581-2594, 1995.

CRAVO, M.S.; VIÉGAS, I.J.M.; BRASIL, E.C. (Ed.). Recomendações de adubação e calagem para o estado do Pará. Belém: Embrapa Amazônia Oriental, 2007. 262p.

DUARTE, O. R. Avaliação quantitativa e análise dos parâmetros biológicos, químicos e físicoquímicos de frutos de Maximiliana maripa (Aubl.) Drude (Inajá) como subsídio do estudo do potencial oleífero de populações promissoras para o Estado de Roraima. 2008. 145 f. Tese (Doutorado em Química) - Universidade Federal do Amazonas, Instituto Nacional de Pesquisas da Amazônia, Manaus, 2008.

EMBRAPA - Empresa Brasileira de Pesquisa Agropecuária. Manual de análises químicas de solos, plantas e fertilizantes. 2. ed. Brasília, DF, 2011. 627p.

KÖPPEN, W. Climatologia: con um estúdio de los climas de la Tierra. México: Fondo de Cultura Economica, 1948. 478p.

KUSNU, M.; SIAHAAN, M. M.; POELOENGAN, Z. Effects of $\mathrm{N}, \mathrm{P}, \mathrm{K}$, and $\mathrm{Mg}$ fertilizer on the growth and yield of oil palm on typic paleudult. In: SUSTAINABILITY OF OIL PALM PLANTATIONS. AGRONOMIC AND ENVIRONMENTAL PERSPECTIVES, 1996, Kuala Lumpu... 14 p.

MATOS, A.K.M.G. Biometria e morfologia de Attalea maripa (Aubl) Mart. (INAJÁ) em sistema silvipastoril no Nordeste Paraense. 2010. $80 \mathrm{f}$. Dissertação (Mestrado em Ciências Florestal) Universidade Federal Rural da Amazônia, Manaus, 2010.
MIRANDA, I. P. A.; RABELO, A. Guia de identificação das palmeiras de um fragmento florestal urbano. Manaus: INPA, EDUA, 2008. $228 \mathrm{p}$.

MOTA, R.V.; FRANÇA, L.F. de. Estudo das características da Ucuuba (Virola surinamensis) e do Inajá (Maximiliana regia) com vistas à produção de biodiesel. Revista Científica da UFPA, Belém, v.6, n.1, 2007. Disponível em: < $\underline{\text { http://www.cultura. }}$ ufpa.br/rcientifica/artigos_cientificos/ed_08/pdf/ rafael vitti.pdf $>$ Acesso em: 29 set. 2015.

OLLINGER, S. V.; SMITH, M. L.; MARTIN, M. E.; HALLETT, R. A.; GOODALE, C. L.; ABER, J. D. Regional variation in foliar chemistry and $\mathrm{N}$ cycling among forests of diverse history and composition. Ecology, Brooklyn, v.83, n. 2, p.339-355, 2002.

PALLET, D. Perspectivas de valorização dos frutos amazônicos obtidos por extrativismo. Montpellier: Cirad. Outubro de 2002. São Paulo: Folha, 2002.

SALM, R.; PRATES, A.; SIMÕES, N. R.; FEDER, L. Palm community transitions along a topographic gradient from floodplain to terra firme in the eastern Amazon. Acta amazônica, v. 45, n. 1, p. 65-74, 2015.

SOH, K. G. Fertilizer use by crop: a global assessment. Beijing: Fertilizer Demand Working Group Meeting, 1997. 6p.

VIEIRA, S. R.; HATFIELD, T. L.; NIELSEN, D. R.; BIGGAR, J. W. Geostatistical theory and application to variability of some agronomical properties. Hilgardia, Berkeley, v.51, n.3, p.1-75, 1983.

ZIMBACK, C.R.L. Análise espacial de atributos químicos de solos para fins de mapeamento da fertilidade. 2001. 114 f. Tese (Livre-Docência) Universidade Estadual de São Paulo, São Paulo, 2001 . 